\section{Complexometric Titration of Co(II) with EDTA Using Succinimide as Indicator}

Komplexometrische Titration von Co(II) mit ÄDTA unter Verwendung von Succinimid als Indicator

\section{L. Sharma}

University of Roorkee (India)

Received February 14, 1970; revised September 1, 1970

Succinimide reacts with $\mathrm{Co}(\mathrm{II})$ in ammoniacal medium to form a deep violet-blue soluble 1:4 (cobalt/succinimide) complex [3]. In course of my study on this reaction, it has been found that succinimide serves as a specific indicator for the complexometric determination of $\mathrm{Co}(\mathrm{II})$ by EDTA titration. This method has the advantages of being very sensitive, specific and less interferring over the existing methods, besides, it gives a very sharp end point unlike some of the well known reagents $[1,2,4]$ where the end point drags on.

Standardized solutions of $\mathrm{Co}(\mathrm{TI})$ nitrate were titrated against EDTA (disodium salt) at room temperature at $\mathrm{pH} 10$ (range 9.5-11). $0.5 \mathrm{~g}$ of succinimide with two drops of strong ammonia was used as indicator. The colour change at the end point was from violet blue to light brown. Better end points are obtained if a small amount of sodium dichromate is added with succinimide. (Colour change from deep-violet blue to yellow.) The concentrations of the $\mathrm{Co}(\mathrm{II})$ solutions should be in the range of 200 to $3000 \mathrm{ppm}$. Every $\mathrm{ml}$ of $0.01 \mathrm{M}$ EDTA corresponds to $0.68 \mathrm{mg}$ of cobalt.

Solutions containing known amounts of $\mathrm{Co}^{2+}$ $(1000 \mathrm{ppm})$ and varying amounts of foreign ions were prepared and $\mathrm{Co}^{2+}$ determined by the above method. $\mathrm{Na}^{+}, \mathrm{K}^{+}, \mathrm{Rb}^{+}, \mathrm{Tl}^{+}, \mathrm{Ag}^{+}, \mathrm{Zn}^{2+}, \mathrm{Ba}^{2+}, \mathrm{Sr}^{2+}$, $\mathrm{Mg}^{2+}, \mathrm{UO}_{2}{ }^{2+}, \mathrm{VO}_{2}{ }^{2+}, \mathrm{B}^{3+}, \mathrm{Cl}^{-}, \mathrm{Br}^{-}, \mathrm{I}^{-}, \mathrm{NO}_{2}{ }^{-}, \mathrm{NO}_{3}{ }^{-}$, $\mathrm{CH}_{3} \mathrm{COO}^{-}$ions do not interfere with the determination even when present in a hundred times the cobalt concentration. $\mathrm{As}^{3+}(400 \mathrm{ppm}), \mathrm{Sb}^{3+}(400 \mathrm{ppm})$, $\mathrm{Mo}^{6+}(500 \mathrm{ppm}), \mathrm{W}^{6+}(500 \mathrm{ppm}), \mathrm{SCN}^{-}(900 \mathrm{ppm})$, $\mathrm{ClO}_{4}^{-}(900 \mathrm{ppm}), \mathrm{AsO}_{4}(500 \mathrm{ppm})$ do not interfere in the concentrations stated. $\mathrm{Be}^{2+}, \mathrm{Mn}^{2+}, \mathrm{Hg}^{2+}, \mathrm{Bi}^{3+}$, $\mathrm{Ce}^{4+}, \mathrm{Th}^{4+}, \mathrm{Zr}^{4+}$ and $\mathrm{Hf}^{4+}$ ions undergo hydrolysis at the $\mathrm{pH}$ of titration and do not interfere when present in $100 \mathrm{ppm}$ concentration. However, $\mathrm{Fe}^{3+}, \mathrm{Cr}^{3+}$ and $\mathrm{CN}^{-}$were found to interfere even in traces. Interferences caused by the following ions can be eliminated by addition of the reagents given in parenthesis; the maximum amount tolerable using these masking reagents is also incorporated: $\mathrm{Ca}^{2+}, \mathrm{Al}^{3+}, \mathrm{Ti}^{3+}$ (sodium fluoride; $500 \mathrm{ppm}$ ), $\mathrm{Cu}^{2+}$ (sodium thiosulphate or ascorbic acid; $1000 \mathrm{ppm}$ ), $\mathrm{C}_{2} \mathrm{O}_{4}{ }^{2-}$ (calcium carbonate and then sodium fluoride; $200 \mathrm{ppm}), \mathrm{Cd}^{2+}, \mathrm{Pb}^{2+}$ (2-mercapto benzothiazole, $900 \mathrm{ppm}$ ). Interference due to $\mathrm{Ni}^{2+}$ may be eliminated by its preliminary separation with dimethylglyoxime in ammoniacal medium.

The relative stabilities of the ammine and succinimide complexes of cobalt are such that the indicator complex is broken down by excess of ammonia. Ammonia is added in such an amount that the required $\mathrm{pH}$ is maintained $(9.5-11)$ during the course of the titration.

\section{References}

1. Flaschka, H.: Mikrochem. verein. Mikrochim. Acta 39, 38 (1952); cf. Z. Anal. Chem. 137, 453 (1952/53).

2. Harris, W. F., Sweet, T. R.: Anal. Chem. 26, 1649 (1954); cf. Z. Anal. Chem. 147, 143 (1955).

3. Malik, W. U., Sharma, C. L.: Z. Anal. Chem. 244, 317 (1969).

4. Vogel, A. I.: Quantitative Inorganic Analysis, IIIrd Edit., p. 443. London: Longmans Green \& Co. 1962.

Dr. C. L. Sharma

Vikasnagar, Residence 150/8

University of Roorkee

Roorkee, India

\section{Indirect Titrimetric Determination of Glucose Using Fehling's Solution and EDTA}

Indirekte volumetrische Glucosebestimmung mit Hilfe von Fehlingscher Lösung und ÄDTA

T. S. B. NarasaraJo, V. L. N. Rao and R. P. Stigh

Department of Chemistry, Banaras Hindu University Banaras, India.

Received June 9, 1970

The earlier methods $[1,3]$ for the determination of glucose based primarily on the reduction of Fehling's solution and the subsequent iodometric determination of either the reduced or the surplus copper were found to be of limited accuracy. The present work has been an attempt to investigate the suitability of complexometric determination of the reduced copper.

Procedure. Solutions were prepared in double-distilled water tested previously for the absence of $\mathrm{Ca}^{2+}$. To a convenient volume of a standard solution of glucose containing not more than $\sim 30 \mathrm{mg}$ were added $5 \mathrm{ml}$ each of Fehling's solutions $A$ and $B$ and then diluted to $50 \mathrm{ml}$ with water. The mixture was heated on a boiling water-bath for exactly $20 \mathrm{~min}$ avoiding bumping, cooled and the cuprous oxide formed was filtered through a 164 crucible, washed repeatedly with water till freed from $\mathrm{Cu}^{2+}$, dissolved in a 